\title{
A Geomechanical Interpretation of the Local Seismicity Related to Eruptions and Renewed Activity on Tolbachik, Koryakskii, and Avacha Volcanoes, Kamchatka, in 2008-2012
}

\author{
A. V. Kiryukhin ${ }^{a}$, S. A. Fedotov ${ }^{a}$, and P. A. Kiryukhin ${ }^{b}$ \\ ${ }^{a}$ Institute of Volcanology and Seismology, Far East Branch, Russian Academy of Sciences, \\ 9 Piipa Boulevard, Petropavlovsk-Kamchatskii, 683006 Russia \\ ${ }^{b}$ OOO Eksidzhen Servisis, Pulkovskoe shosse 40-1, St. Petersburg, 196158 Russia \\ e-mail: AVKiryukhin2@mail.ru \\ Received May 11, 2016
}

\begin{abstract}
The local seismicity during the 2012-2013 eruption of Tolbachik Volcano and the 2008-2009 steam-gas eruption of Koryakskii Volcano is here considered as resulting from injections of magma that produced dikes, sills, and renewed activity at preexisting faults. We identified plane-oriented earthquake clusters in order to reveal the above zones using earthquake catalogs made at the Kamchatka Branch of the Geophysical Service of the Russian Academy of Sciences (KB GS RAS). Subsequent space-time analysis of these observations lends itself to the following interpretation. The November 27, 2012 Tolbachik lava eruption was preceded by an injection of magma resulting in a series of dikes trending west-northwestward in the range of absolute depths between -4 and $+3 \mathrm{~km}$ in a zone situated southeast of the Ploskii Tolbachik Volcano edifice. The dikes penetrated into a nearly horizontal permeable zone at an absolute depth of approximately zero, producing sills and emplacing a magma-conducting dike along the top of the zone of cinder cones (the dip angle is $50^{\circ}$ toward the azimuth $300^{\circ}$ ) $5.5 \mathrm{~km}$ from the epicenter of the initial magma injection. The summit steamgas eruption of Koryakskii Volcano in 2008-2009 was preceded by magma filling a crustal chamber (the top of the chamber is at $-3 \mathrm{~km}$ absolute depth; the chamber is $2.5 \mathrm{~km}$ across) close to the southwestern base of Koryakskii. Further, magma injection in a nearly north-south zone ( 7.5 by $2.5 \mathrm{~km})$, the absolute depth between -2 and $-5 \mathrm{~km}$ ) in the north sector of Koryakskii Volcano was occurring concurrently with the summit steam-gas eruption. The injection of magma into the cone of Avacha Volcano (2010) produced sills (at altitudes between +1600 and $+1900 \mathrm{~m}$ ) and dikes (mostly striking northwest).
\end{abstract}

DOI: $10.1134 / \mathrm{S} 0742046316040047$

\section{INTRODUCTION}

Parasitic eruptions on andesitic volcanoes and fissure eruptions in the radial zones of cinder cones associated with such volcanoes give rise to new magma conduits to supply material for the eruptions. Magma conduits of this kind were formed before the onset of an eruption and during the eruption itself and have the shapes of dikes, sills, laccoliths, and stocks. The study of the generation, structure, and properties of such bodies is an important task that is facing volcanology and the theory of generation for geothermal, oil, gas, and ore fields. The goal of the present study is to evaluate whether it is possible to determine the geometry of plane-oriented magma conduits beneath volcanoes (dikes and sills) from seismic data with subsequent geomechanical interpretations of these determinations.

Basic information on the depths and dimensions of magma conduits beneath Ploskii Tolbachik Volcano can be found in Fedotov et al. (2011). The concepts proposed in this paper are based on geological, seismological, and geodetic data and used simulation results for the melting of a magma chamber beneath Ploskii Tolbachik. According to these concepts, there is a peripheral magma chamber beneath Ploskii Tolbachik whose lateral dimensions are within $6 \mathrm{~km}$, the top of the chamber is at a depth of $2 \mathrm{~km}$ below sea level, its vertical extent is $3.2-3.9 \mathrm{~km}$, and the volume is $40-70 \mathrm{~km}^{3}$.

There are certain geological and geophysical data from which one can obtain an approximate estimate of the geometry of the magma chamber beneath Avacha Volcano, viz., an ellipsoid (Fedotov, 2006; Fedotov et al., 2007): the top of the magma chamber is estimated to be between zero sea level and $2 \mathrm{~km}$ below sea level, the horizontal and vertical semi-axes of the ellipsoid as delineated by the $900^{\circ} \mathrm{C}$ isotherm are between 2.3 and $1.53 \mathrm{~km}$, with the respective figures based on the $700^{\circ} \mathrm{C}$ isotherm being 4.5 and $3 \mathrm{~km}$. 
Exploitation of the underground circulation system for 100 years can yield approximately $250 \mathrm{MW}$ of electrical energy due to a hot rock block of approximately $50 \mathrm{~km}^{3}$ in volume (Fedotov, 2006; Fedotov et al., 2007). Renewed exploration for sources of geothermal heat and electrical supply in the area of the Koryakskii-Avacha volcanic cluster (R.I. Pashkevich, personal communication, 2015) makes it necessary to conduct research on the distribution of active magma bodies and the mechanism of magma transport in conduits of volcanoes.

We wish to list a number of results from the study of the 1975-1976 Great Tolbachik Fissure Eruption (GTFE): vertical ascent of magmas along fissures before the generation of new large cones referred to by numbers: I, II, III, and VIII; the formation of a shallow sill that supplied material for smaller cones IV through VII; the formation of a laccolith under Cone I whose base had been rising until the appearance of the lava bocche, which began to descend when large amounts of lava were effused from these cones; and the probable emplacement of sills from the Ploskii Tolbachik peripheral chamber toward the southwest, while its summit caldera collapsed by $300 \mathrm{~m}$, among other occurrences (Bol'shoe treshchinnoe ..., 1984).

Volcanoes and crustal magma chambers result from magma ascending from primary magma chambers at depths of 150-200 km (Fedotov, 2006, among others). The crustal magma chambers are fed with magma from primary magma reservoirs (zones of magma accumulation) and supply material for the formation of inclined dikes, sills and dikes, including magma-feeding dikes that produce the ejection of magma onto the ground surface and supply material for the generation of volcanic edifices themselves. The formation of sills and dikes during initial emplacement through the viscous shells of magma chambers expands the chambers.

Many dikes are "frozen" in the host rocks and do not reach the ground, some change their orientations during propagation and become sills. Changes in dike orientation and the transformation of dikes into sills are frequently observed in stratiform reservoirs that involve normal faults. A review of paleovolcanological evidence and of the existing thermohydrodynamic models for magma chambers shows the following (Gudmudsson, 2012): (1) Many crustal magma chambers are produced from sills; (2) Active crustal magma chambers inject magma into associated volcanoes, with most chambers being in a partially molten (porelike) state; (3) The thermally stable shape of magma chambers is an ellipsoid; (4) Discussion of hydraulic fracturing and injection of dikes should consider the excess pressure of magma (the strength of the host rocks to resist fracture, which is $1-6 \mathrm{MPa}$ ); (5) The excess pressure is decreasing during eruptions in an exponential manner, until the dike loses its hydraulic connection to the chamber; (6) The pressure of magma in a chamber during a repose period must equal the overall lithostatic pressure; (7) the conditions that lead to hydraulic fracture on the top of a magma chamber are reached in two ways, viz., either increasing absolute pressure of the magma in the chamber due to injection from the magma reservoir or by decreasing horizontal stress due to regional extension; (8) the local stress field around a magma chamber depends on the chamber shape and depth, as well as the geomechanical properties and layering of the host rocks.

The above discussion shows that the injection of magma from crustal magma chambers with the generation of dikes and sills due to magma-driven fracture are largely analogous to the injection of fluids into wells with subsequent hydraulic fracturing and fissure generation in the host formations. Our argument in what follows will therefore make use of the term magma-driven fracture in application to magma processes in order to describe the formation of plane-oriented features (dikes, inclined dikes, sills, large fissures and faults) that occur during renewed activity of crustal magma chambers beneath volcanoes.

The data from observations of oil, gas, and geothermal fields as fluids are injected into wells are widely used to evaluate the state of stress in the associated rock mass. Numerous observations show that the plane of a hydraulic fracture fissure is oriented perpendicularly to the axis of least stress.

Hydraulic fracturing is made more difficult when the fluid is subject to "freezing" because in this case one needs greater discharge rates to maintain the thermal balance above the solidus. For this reason magma injections in the form of dikes must have larger apertures (up to 1-10 m), which follows both from theoretical calculations (Bol'shoe ..., 1984) and from geological observations.

The description of the state of stress in a rock mass rests on three principal stresses: vertical stress $(\mathrm{Sv})$, the greatest horizontal stress (Shmax), and the least horizontal stress (Shmin) (Zoback, 2010, pp. 8-12). In application to magma injection into the plumbing system of a volcano, one can believe that horizontal extension of the crust (rift zones, grabens, Sv $>$ Shmax $>$ Shmin) will mostly favor dike generation, while horizontal compression (horsts, Shmax $>\mathrm{Shmin}>\mathrm{Sv}$ ) is a favorable setting for sill emplacement. It should also be borne in mind that magma injection can cause changes in stress around the volcanic edifice during the precursory period and occurrence of an eruption, that is, the occurrence of magma injection (such as a dike or a sill) depends on time. 
The formation of new fissures by hydraulic fracturing and renewal of activity on pre-existing faults is accompanied by microseismicity due to the generation of shear fissures in the zone immediately adjacent to the main aseismic zone of a hydraulic fracture fissure (trigger seismicity). For this reason it may be hypothesized that the planes that fit microearthquake clusters have the same orientation with the hydraulic fracture fissures during injection (emplacement) of magma. The magnitudes of strike-slip earthquakes with slip amplitudes of $0.1 \mathrm{~mm}$ to $1 \mathrm{~cm}$ and fissure lengths of a few hundreds of meters are estimated to lie in the range between 1 and 2 (Ks between 3.5 and 5.5). This is consistent with the sensitivity of the local seismograph networks that are operated in the area of Tolbachik Volcano and in the Koryakskii-Avacha volcanic cluster.

In this paper we treat the emplacement of magma in a fissured porous medium by analogy with filtration in earth (where magma is the fluid), which is to some extent based on V.V. Ivanov's ideas (Ivanov, 2015) on the origin of microseismicity during magma emplacements. This approach to the problem is also motivated by the observations reported by Sigmundsson et al. (2015), who described the injection of magma from the magma chamber beneath the Barparbunga central-type volcano, Iceland, which occurred in August 2014 and was accompanied by a dike that propagated for a distance of $45 \mathrm{~km}$.

In view of the above, we aimed to identify planeoriented clusters of earthquakes (as explained above) using the seismic events observed before the lava eruption of November 27, 2012 on Tolbachik Volcano and before the 2008-2009 burst of activity in the Koryakskii-Avacha volcanic cluster (Section 2), performing a subsequent analysis of the possible spatial distribution of dikes and sills in the edifices and bases of these volcanoes (Sections 3 and 4), and using Mohr's diagrams to evaluate the consistency with the geomechanical criteria for strike-slip fissures and the pressure of magma that is required for their renewed activity (Section 5). This study is largely based on previous materials for the lava eruption of 2012-2013 on Tolbachik Volcano. Section 3.1 is concerned with an analysis of these materials.

\section{DATA AND ALGORITHM FOR SELECTION AMONG PLANE-ORIENTED CLUSTERS OF MICROEARTHQUAKES.}

\subsection{The Data}

Local earthquakes in the area of Tolbachik volcanoes were recorded in 2012-2013 by the Klyuchevskoi network of radio telemetry stations operated by the KB GS RAS, which includes 12 stations. Five of these
(Fig. 1) can record earthquakes with magnitudes as low as -1 or 2 on Ploskii Tolbachik Volcano.

Fedotov et al. (2014) constructed and analyzed vertical geophysical cross sections for the area of study with the hypocenters superposed. The absolute location uncertainty, both for hypocenters and epicenters, is estimated as $3 \mathrm{~km}$ for the time span around the 2012 Tolbachik eruption (Zemletryaseniya ..., 2014).

Kugaenko et al. (2014) identified phases in seismic activity increase and its spatial distribution in the Ploskii Tolbachik area prior to the November 27, 2012 eruption, including a statistically significant seismicity increase from July to October 2012 (Ks = 4-6), with the seismicity level reaching extremely high values 3 weeks before the start of the eruption, and the larger earthquakes (Ks $=7-9)$ during a few hours before the start. As the eruption started (November 30 to December 7, 2012), seismic activity moved $10 \mathrm{~km}$ south into the Tolud seismic zone $(\mathrm{Ks}=5.2-11.3)$.

Six stations can record seismicity in the AvachaKoryakskii volcanic cluster (Fig. 2). The absolute location uncertainty for the hypocenters and epicenters of microearthquakes in this area is estimated as $1 \mathrm{~km}$ (Zemletryaseniya ..., 2014).

It also appears from the relevant catalogs that earthquakes with similar places and times of occurrence show similar errors of their origin time, that is, they involve a bias. This suggests that the relative location errors for the earthquakes are much worse for clusters of nearby events. As an example, events VLN127128-VLN127172 (Zemletryaseniya ..., 2014), which constitute cluster 39 (table), show standard origin time errors that are lower by an order of magnitude compared with all of the events in the catalog. This finding suggests that the relative location uncertainty for clusters of nearby events should be acceptable for the identification of plane-oriented features of a few kilometers across. It is also obvious that an accidental shift of coordinates would make the probability of not occurring in a plane-oriented cluster much greater than that of occurring in the cluster. For this reason, when events seem to acquire a geometric pattern, in spite of their location uncertainties, this would point to a certain physical meaning of the occurrence.

\subsection{An Algorithm for Selecting Plane-Oriented Clusters of Microearthquakes and for Estimating the Parameters of the Associated Planes}

Cluster identification was carried out using our program in the Java Development Kit 8 (jdk-8u40windows-x64). The following criteria were used for including a new event in a cluster: (1) a small time difference $(\Delta t=1$ day); (2) a small distance difference in the horizontal plane $(\Delta R<6 \mathrm{~km})$; (3) a nearly planar orientation (a distance from the event to the plane $(\Delta Z)$ below $200 \mathrm{~m})$. Subsequent discussion will focus 


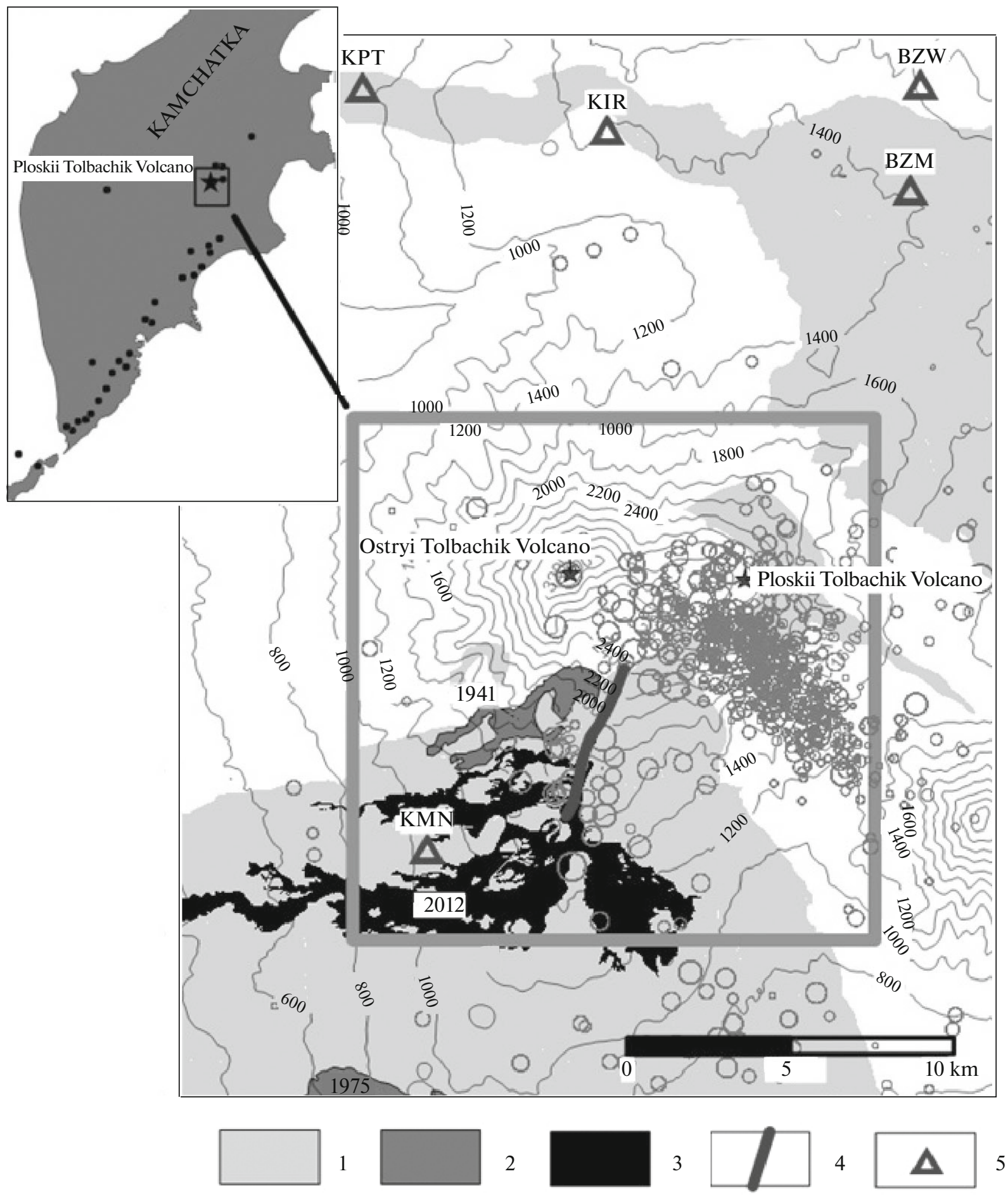

Fig. 1. A map of Tolbachik Volcano area. (1) Holocene lavas; (2) lavas of historical eruptions (the 1941 vent and the 1975 North Vent); (3) lavas of the 2012-2013 eruption; (4) projection of the November 27, 2012 Tolbachik Fissure Eruption fissure onto the ground surface; (5) the KB GS RAS seismograph stations with the station name abbreviated. The epicenters of the 2012-2013 earthquakes (data from KB GS RAS) are shown as circles (proportional to energy class Ks from 2.6 to $11.3, \mathrm{M}=0.5 \mathrm{Ks}-0.75$ ), the inner rectangle encloses the 3D model in Fig. 5. The isolines show the topographic surface. 


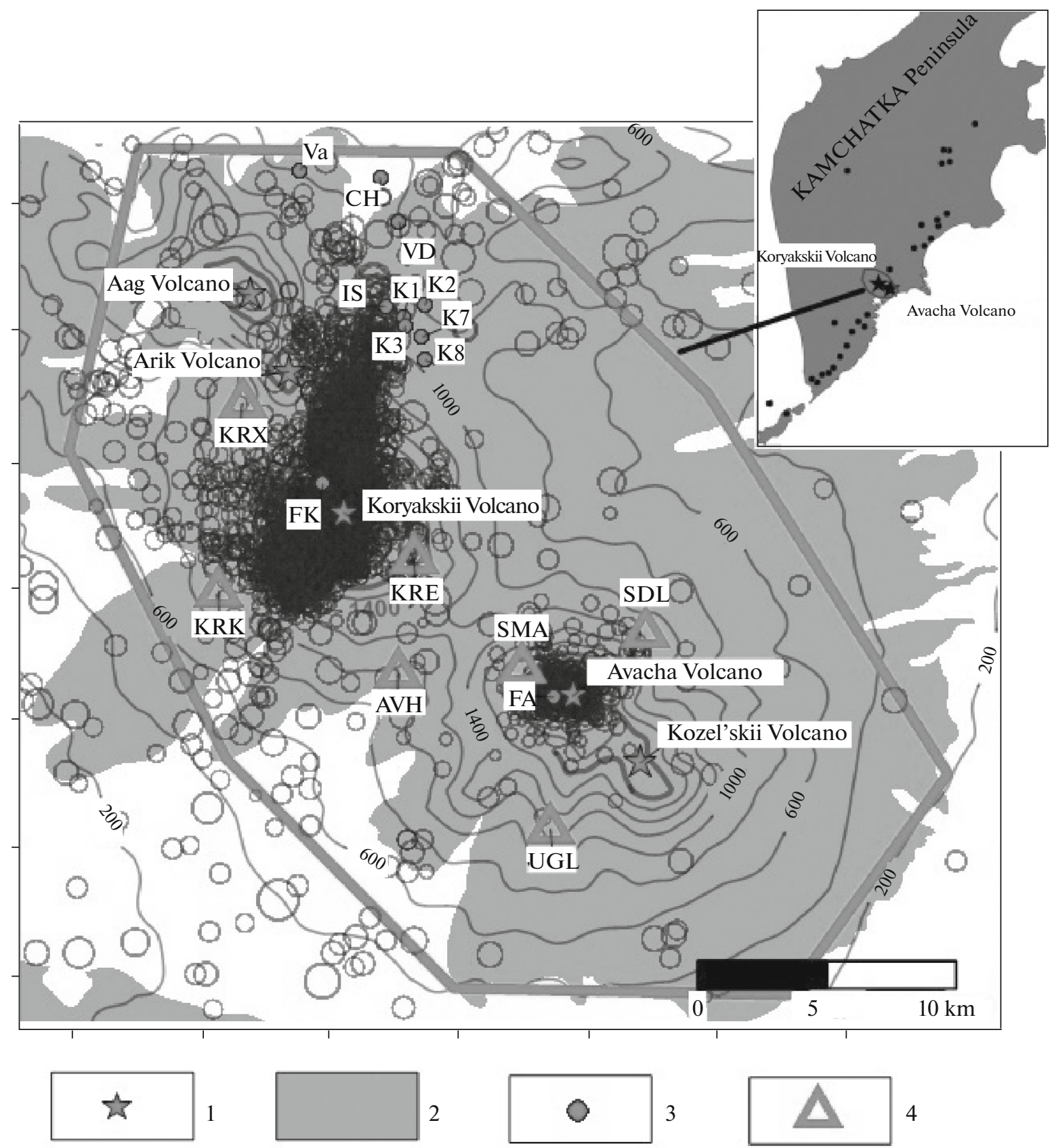

Fig. 2. A map of the Koryakskii-Avacha volcanogenic basin. (1) the summits of the Avacha, Koryakskii, Kozel'skii, Arik, and Aag volcanoes; (2) ejecta of volcanic eruptions indicated above; (3) thermal occurrences: FA, fumaroles on Avacha Volcano, FK fumaroles on Koryakskii Volcano; thermal mineral springs: K1, K2, K3, K7, K8 are Koryakskii Narzany; IS, Izotov; VD, Vodopadnyi; CH, Chistinskie; Va, Vakinskii; (4) the KB GS RAS seismograph stations. Epicenters of the 2000-2013 earthquakes (data from the KB GS RAS) are shown as circles (proportionally to energy class Ks from 1.1 to 8.5 , $\mathrm{M}=0.5 \mathrm{Ks}-0.75$ ). Inner polygon encloses the 3D model in Fig. 6. The isolines show the topographic surface, the ticks along the axes stand at intervals of $5 \mathrm{~km}$.

on clusters with the number of elements $(N)$ greater than 5.

Cluster selection. We tested all of the initially selected earthquakes on the main list for the above three requirements. When the resulting cluster contains more than five elements $(N>5)$, that cluster was treated as completed and was added to the list of clus- ters. This procedure was reiterated until the main list of elements was exhausted.

Calculation of parameters for a plane-oriented cluster. The raw data consist of a list of cluster elements. Each element $i$ contains the coordinates $\left(x_{i}, y_{i}, z_{i}\right)$. For $n$ (the number of elements in the cluster) points with coordinates $\left(x_{i}, y_{i}, z_{i}\right)$ we find the equation of the fit- 
Identified plane-oriented clusters of earthquakes from the 2012-2014 catalog of seismic events for the area of Tolbachik Volcano and the parameters of the planes that fit them

\begin{tabular}{c|c|c|c|c|c|c|c|c}
\hline Cluster no. & $\begin{array}{c}\text { Angle } \\
\text { of dip, } \\
\text { deg }\end{array}$ & $\begin{array}{c}\text { Azimuth } \\
\text { of dip, } \\
\text { deg }\end{array}$ & $X, \mathrm{~m}$ & $Y, \mathrm{~m}$ & $Z, \mathrm{~m}$ abs. & $\begin{array}{c}\text { Beginning } \\
\text { of cluster } \\
\text { DD/MM/YY } \\
\text { HH:MM }\end{array}$ & $\begin{array}{c}\text { Number } \\
\text { of earthquakes } \\
\text { in cluster }\end{array}$ & $\begin{array}{c}\text { Cluster } \\
\text { area, km }\end{array}$ \\
\hline 18 & 80 & 137 & 588041 & 6185570 & -2369 & $25.11 .1210: 56$ & 8 & 8.8 \\
19 & 25 & 230 & 589355 & 6185175 & -3256 & $25.11 .1220: 29$ & 27 & 6.6 \\
20 & 44 & 148 & 588412 & 6185393 & -2422 & $25.11 .1222: 00$ & 19 & 0.7 \\
21 & 32 & 250 & 588749 & 6185321 & -2893 & $26.11 .121: 12$ & 28 & 0.6 \\
22 & 58 & 74 & 588183 & 6185916 & -1727 & $26.11 .126: 06$ & 27 & 8.8 \\
23 & 77 & 209 & 587489 & 6186380 & -1887 & $26.11 .126: 59$ & 31 & 1.6 \\
24 & 62 & 6 & 588037 & 6185744 & -2536 & $26.11 .129: 29$ & 17 & 17.9 \\
25 & 42 & 112 & 587506 & 6185373 & -3030 & $26.11 .1215: 12$ & 9 & 15.3 \\
26 & 46 & 233 & 587490 & 6186646 & -1162 & $26.11 .1217: 02$ & 11 & 10.5 \\
27 & 52 & 138 & 588833 & 6185808 & -1454 & $26.11 .1218: 50$ & 20 & 16.1 \\
28 & 27 & 245 & 589936 & 6184132 & -3135 & $26.11 .1219: 51$ & 17 & 3.7 \\
29 & 61 & 53 & 587366 & 6185779 & -263 & $26.11 .1220: 58$ & 12 & 1.8 \\
30 & 59 & 20 & 586981 & 6185946 & -818 & $26.11 .1223: 04$ & 12 & 9.7 \\
31 & 62 & 208 & 589346 & 6185416 & -1780 & $26.11 .1223: 16$ & 13 & 21.2 \\
32 & 63 & 18 & 587227 & 6186504 & -797 & $26.11 .1223: 45$ & 7 & 10.4 \\
33 & 60 & 197 & 588391 & 6186634 & -2127 & $27.11 .120: 19$ & 7 & 7.5 \\
34 & 75 & 192 & 585967 & 6186785 & -2147 & $27.11 .120: 38$ & 6 & 21.2 \\
35 & 74 & 213 & 591075 & 6183134 & -1053 & $27.11 .122: 26$ & 6 & 5.7 \\
36 & 83 & 98 & 589811 & 6184397 & -1122 & $27.11 .123: 16$ & 6 & 1.5 \\
$\mathbf{3 7}$ & $\mathbf{3}$ & $\mathbf{1 3 5}$ & $\mathbf{5 8 9 3 0 7}$ & $\mathbf{6 1 8 3 3 9 1}$ & $-\mathbf{1 7 7}$ & $\mathbf{2 7 . 1 1 . 1 2 ~ 3 : 5 5}$ & $\mathbf{9}$ & 13.1 \\
$\mathbf{3 8}$ & $\mathbf{5 5}$ & $\mathbf{3 0 0}$ & $\mathbf{5 8 3 3 7 8}$ & $\mathbf{6 1 8 3 0 7 9}$ & $\mathbf{3 0 2}$ & $\mathbf{2 7 . 1 1 . 1 2 ~ 5 : 3 5}$ & $\mathbf{6}$ & 4.0 \\
$\mathbf{3 9}$ & $\mathbf{7}$ & $\mathbf{1 9 6}$ & $\mathbf{5 8 3 2 6 9}$ & $\mathbf{6 1 8 1 4 1 4}$ & $\mathbf{- 3 5}$ & $\mathbf{2 7 . 1 1 . 1 2 ~ 7 : 0 9}$ & $\mathbf{1 2}$ & 8.9 \\
\hline
\end{tabular}

$X, Y$, and $Z$ are the coordinates of cluster centers (in the UTM WGC-84 system).

ting plane $z=a x+b y+c$ by the least-squares method. The solution thus reduces to solving a set of linear equations as follows:

$$
\left[\begin{array}{ccc}
\sum x_{i}^{2} & \sum x_{i} y_{i} & \sum x_{i} \\
\sum x_{i} y_{i} & \sum y_{i}^{2} & \sum y_{i} \\
\sum x_{i} & \sum y_{i} & n
\end{array}\right]\left[\begin{array}{l}
a \\
b \\
c
\end{array}\right]=\left[\begin{array}{c}
\sum x_{i} z_{i} \\
\sum y_{i} z_{i} \\
\sum z_{i}
\end{array}\right] .
$$

These equations are solved using Cramer's rule.

In this way we obtain the coefficients $a, b, c$ for the equation of a plane, $z=a x+b y+c$. The next step is to find the unit vector that is normal to the fitting plane $\mathbf{n}=(a / \Delta, b / \Delta,-1 / \Delta)$, where $\Delta$ is the determinant of the equations that result in geological parameters, viz., dip angle $\beta=\arccos (1 / \Delta) \times 180 / 3.142$ and the azimuth of dip $\arctan (a / b) \times 180 / 3.142$.

An analysis of the sensitivity for this algorithm where plane-oriented clusters are selected according to the criteria of temporal and spatial proximity shows that the above criteria make the selection results reasonable, both in physical and geological terms.

The KB GS RAS catalog of local earthquakes (1262 events for the period of January 1, 2012 to December 31, 2013) was inspected to select 310 events that occurred in the area of the Tolbachik volcanoes. These events make up 22 plane-oriented clusters that immediately preceded the November 27, 2012 eruption. The table shows results from identification of plane-oriented earthquake clusters using the criteria described above, as well as structural and geological characteristics of the relevant planes (angle of dip, azimuth of dip, the coordinates of cluster centers, the times of occurrence, and the numbers of earthquakes). The fact that the time interval $\Delta t$ used to select planeoriented clusters was increased (reaching 2 days) did not appreciably affect the cluster identification. This shows that each new dike or sill does not coincide with 


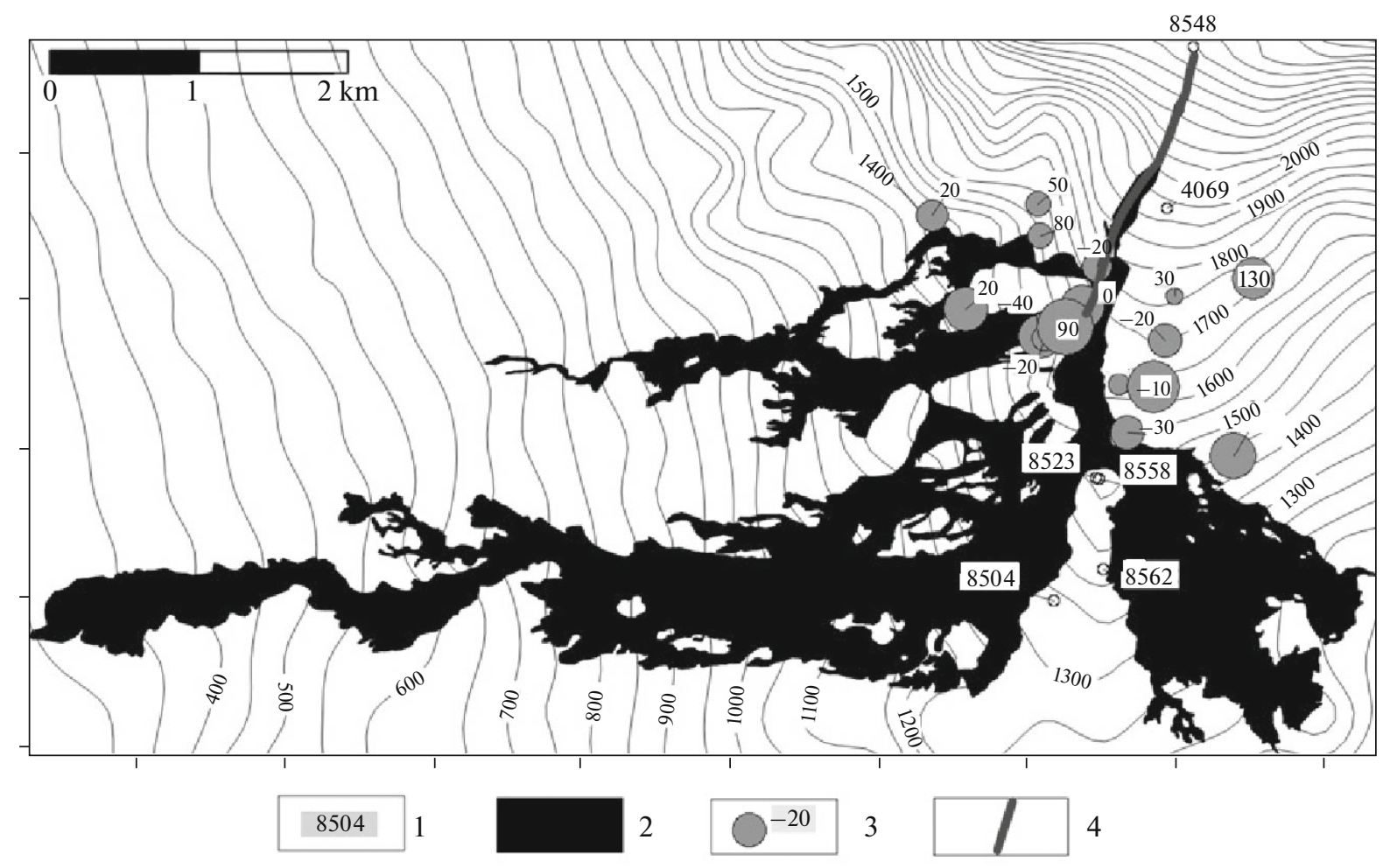

Fig. 3. A map of the epicenters for the last precursory cluster of earthquakes, lava flows, and sites where fissures were measured in the area of the 2012-2013 Tolbachik eruption. A map of measurement sites in the area of the 2012-2013 Tolbachik eruption, with some of these being shown in the photograph of Fig. 4. The area is enclosed by the outlines of the lava flow discharged by the 2012-2013 Tolbachik eruption. The locations of the lava flows discharged by the 2012-2013 Tolbachik eruption, Kamchatka are shown in Fig. 1. (1) sites of fissure measurements (numerals in rectangles correspond with the photograph of Fig. 4); (2) outlines of the 2012-2013 Tolbachik lava flows (Volynets et al., 2013); (3) epicenters of local earthquakes, UTC 7:25-7:57, November 27, 2012 (data are from the KB GS RAS), numerals denote absolute depths in meters (earthquakes are from cluster 39, see table); (4) projection of the eruptive fissure of the November 27, 2012 Tolbachik Fissure Eruption onto the ground surface. Isolines show the topographic surface, ticks stand at intervals of $2 \mathrm{~km}$.

any of the preceding ones in space. We also note that only four plane-oriented clusters were identified after the start of the November 27, 2012 eruption and until the end of 2013. These clusters occurred in the location of the Tolud set of earthquakes (November 30, 2012 to December 4, 2012) $10 \mathrm{~km}$ south of the eruption centers. One of the clusters is interpreted as a sill at an absolute altitude of $-260 \mathrm{~m}$, possibly indicating a hydraulic connection between the sill and the system of magma-conducting conduits that supplied magma for the November 27, 2012 eruption (clusters 37 and 39 , see the table).

A total of 3922 earthquakes have been recorded by the KB GS RAS to occur in the edifices and basement of the Koryakskii-Avacha Volcanic Cluster during the period between January 2000 and February 2013. Our treatment of this data set using the method outlined above yielded 1310 earthquakes that make up 164 planeoriented clusters for the period between January 2008 and August 2011.

\subsection{An Analysis of Sensitivity of the Algorithm for Selecting Plane-Oriented Clusters from among Random Uncertainties Inherent in Microearthquake Location}

According to V.V. Ivanov (personal communication, 2015), clusters of volcanic earthquakes consist of thousands or tens of thousands of events, which coalesce to form a continuous record such as volcanic tremor during increases of seismicity. Each earthquake arrives on the background of the preceding one; one can distinguish the onsets of $\mathrm{P}$ and $\mathrm{S}$ waves and locate them using classical seismological techniques for very few events.

Our analysis of sensitivity for the determination of the parameters of plane-oriented microearthquake clusters (angle of dip and azimuth of dip), as affected by the random component in the location uncertainty, was based on an earthquake catalog for the area of Tolbachik Volcano (2012-2013); the procedure was as follows. The earthquake coordinates were shifted by computer-generated random values that followed the 

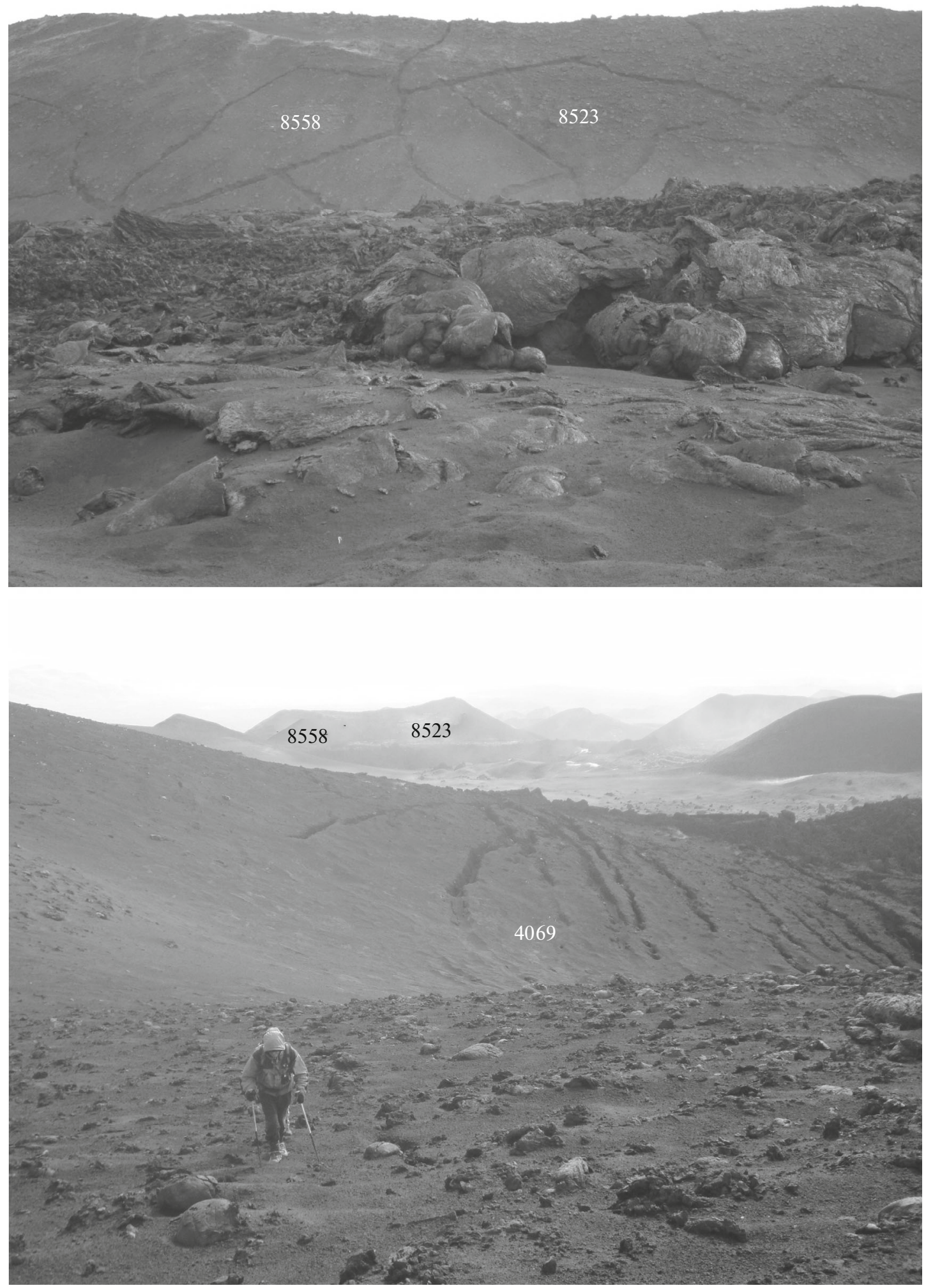

Fig. 4. Photograph of fissures at measurement sites shown in Fig. 3. The top photograph shows polygonal fissures (sites 8504 , 8523,8558 , and 8562) (open polygonal fissures indicate an extensional setting, which is possible, when the vertical stress is much larger than the horizontal one, which may be the case in sill emplacement). The bottom photograph shows open linear fissures whose predominant strike azimuth is $340^{\circ}$ (site 4069) (open linear fissures at $45^{\circ}$ relative to the main magma-conducting fissure indicate its strike-slip character). 
normal Gauss law with different rms deviations $\sigma(125$, $250,500,1000$, and $3000 \mathrm{~m})$. We used the algorithm, as described in Section 2.2, to select plane-oriented clusters of earthquakes and to estimate the cluster parameters (angle and azimuth of dip). These were then displayed graphically in polar coordinates with different values of $\sigma$. The results of this analysis showed that the parameters of plane-oriented clusters remained the same when the random component $\sigma$ did not exceed $0.5 \mathrm{~km}$. It was also found that when the criterion for cluster elements to lie on a plane was increased the nearby clusters may coalesce.

\section{A GEOMECHANICAL INTERPRETATION: THE NOVEMBER 25-27, 2012 SEQUENCE OF MAGMA INJECTIONS BEFORE THE ERUPTION OF TOLBACHIK}

\subsection{Interpretation of Satellite, Ground Deformation, and Field Measurements of Cracking}

The last fissure eruption started on the south slope of Tolbachik on November 27, 2012 and continued for 9 months. The total volume of ejecta is estimated as $0.55 \mathrm{~km}^{3}$, with an area of $36 \mathrm{~km}^{2}$; the magma discharge reached $440 \mathrm{~m}^{3} / \mathrm{s}$, gradually diminishing from 140 to $18 \mathrm{~m}^{3} / \mathrm{s}$ (Belousov et al., 2015). The eruption substantially altered the volcano's landscape after the Great Tolbachik Fissure Eruption of 1975-1976 (Fedotov et al., 1991).

Ground deformation that occurred during the 2012-2013 eruption was estimated from multiple satellite-based radar observations (interferometric synthetic aperture radar (InSAR)), with the data from the Canadian Space Agency's RADARSAT-2 and Italian Space Agency's COSMO-SkyMed (Lundgren et al., 2015). Climatic conditions (snow cover) make comparison of interferograms only feasible for surveys conducted in August-September 2012 and 2013. Our $3 \mathrm{D}$ geomechanical model describes the deformation observed during the time span of interest (1 year) as being the result of the emplacement of a radial dike into Tolbachik Volcano (the angle of dip is $80^{\circ}$ to the west-northwest).

The monitoring of ground deformation by GPS observation (Kugaenko et al., 2015) shows a dramatic subsidence of $30-40 \mathrm{~cm}$ that was simultaneous with the start of the November 27, 2012 eruption and a displacement toward the eruption center (an azimuth of $\approx 210^{\circ}$ ) in the Klyuchevskoi Volcanic Cluster area at a distance of $45-70 \mathrm{~km}$. These observations point to a hydraulic connection between the plumbing systems of the Klyuchevskoi Volcanic Cluster and the Tolbachik Volcanoes.

Our field observations of parameters of open fissures conducted by the present authors in the eruption area in September 2013 shows the following: (1) The main magma-conducting fissure strikes $25^{\circ}$; (2) Open fissures (with separations as large as $0.5-1.0 \mathrm{~m}$ ) that strike northwest-west at $340^{\circ}$ prevail east of the main magma-conducting fissure; (3) Polygonal open (up to 0.5-1.0 m separation) fissures occur on the slopes of Kleshnya Cone (south of the main eruption center) (Figs. 3 and 4). The open linear fissures that strike at $45^{\circ}$ relative to the main magma-conducting fissure indicate that this is a strike-slip feature. The polygonal open fissures indicate radial extension, which is possible when vertical stress is much greater than the horizontal $(\mathrm{Sv}>\mathrm{Shmax}=$ Shmin, $($ Zoback, 2010, p. 9) $)$. This could occur during sill emplacement.

To sum up, although a geomechanical model that involves a single dike can explain the net ground deformation effect, it can hardly be expected to provide an adequate description for the sequence of emplacements of magma bodies that preceded the November 27, 2012 eruption. In this connection we are going to discuss how local seismicity data can be used to reconstruct the sequence of magma injections prior to the Tolbachik eruption.

\subsection{A Geomechanical Interpretation of the Local Seismicity}

The identified plane-oriented clusters of earthquakes (see table) are interpreted as sills and dikes resulting from magma injection. If this hypothesis is justified, it follows that the Tolbachik eruption was preceded by approximately 20 dike emplacements due to magma injection (mostly striking west-northwest) in the range of absolute depths between -4 and $+3 \mathrm{~km}$ in a zone southeast of the Ploskii Tolbachik volcanic edifice (see table, clusters 18-36; Fig. 5a). This led to the opening of nearly horizontal permeable reservoirs and produced conditions for the injection of two sills $(0 \mathrm{~km}$ abs. $)$ and of a magma-conducting dike striking northeast-north at $30^{\circ}$ (see table, earthquake clusters 37-39; Fig. 5b), resulting in the November 27, 2012 Tolbachik eruption.

We wish to note that the azimuth of the magmaconducting dike, viz., $30^{\circ}$ (see table, cluster 38 ) as estimated from seismic data is quite consistent with field observations $\left(25^{\circ}\right)$ and satellite-based ground deformation observations by InSar (Lundgren et al., 2015), while clusters 37 and 39 (see table) which are identified as sills, are consistent with observations of polygonal fissures (see Figs. 3 and 4).

\section{A GEOMECHANICAL INTERPRETATION: THE SEQUENCE OF MAGMA INJECTIONS IN THE KORYAKSKII-AVACHA VOLCANIC CLUSTER DURING THE 2000-2012 PERIOD.}

\subsection{Brief Information on the 2008-2009 Steam-Gas Eruption of Koryakskii Volcano (Ivanov, 2010)}

A visible renewal of activity on Koryakskii Volcano started November 23, 2008 (increased steam-gas activity in a fissure on the northwestern slope of the 
(a)

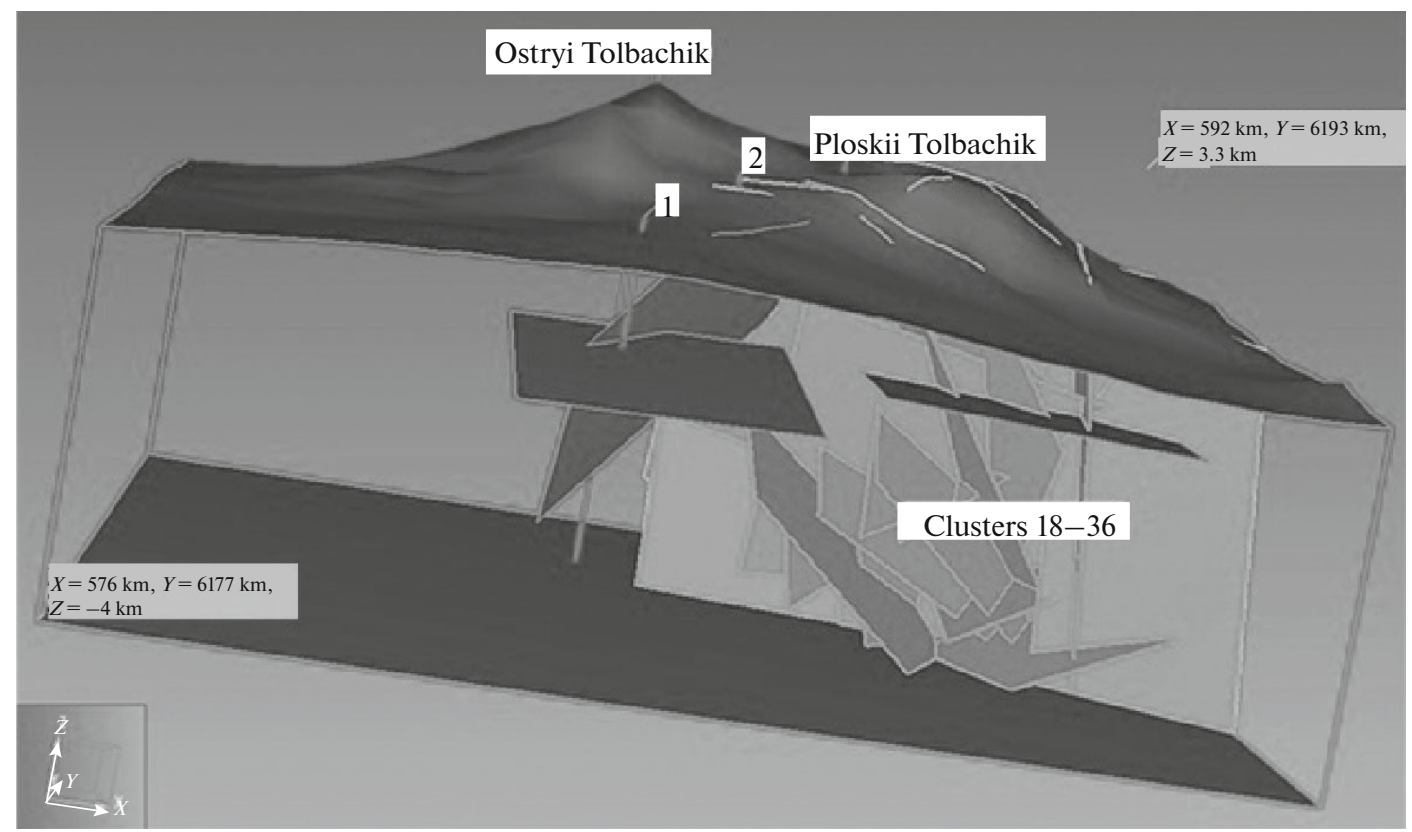

(b)

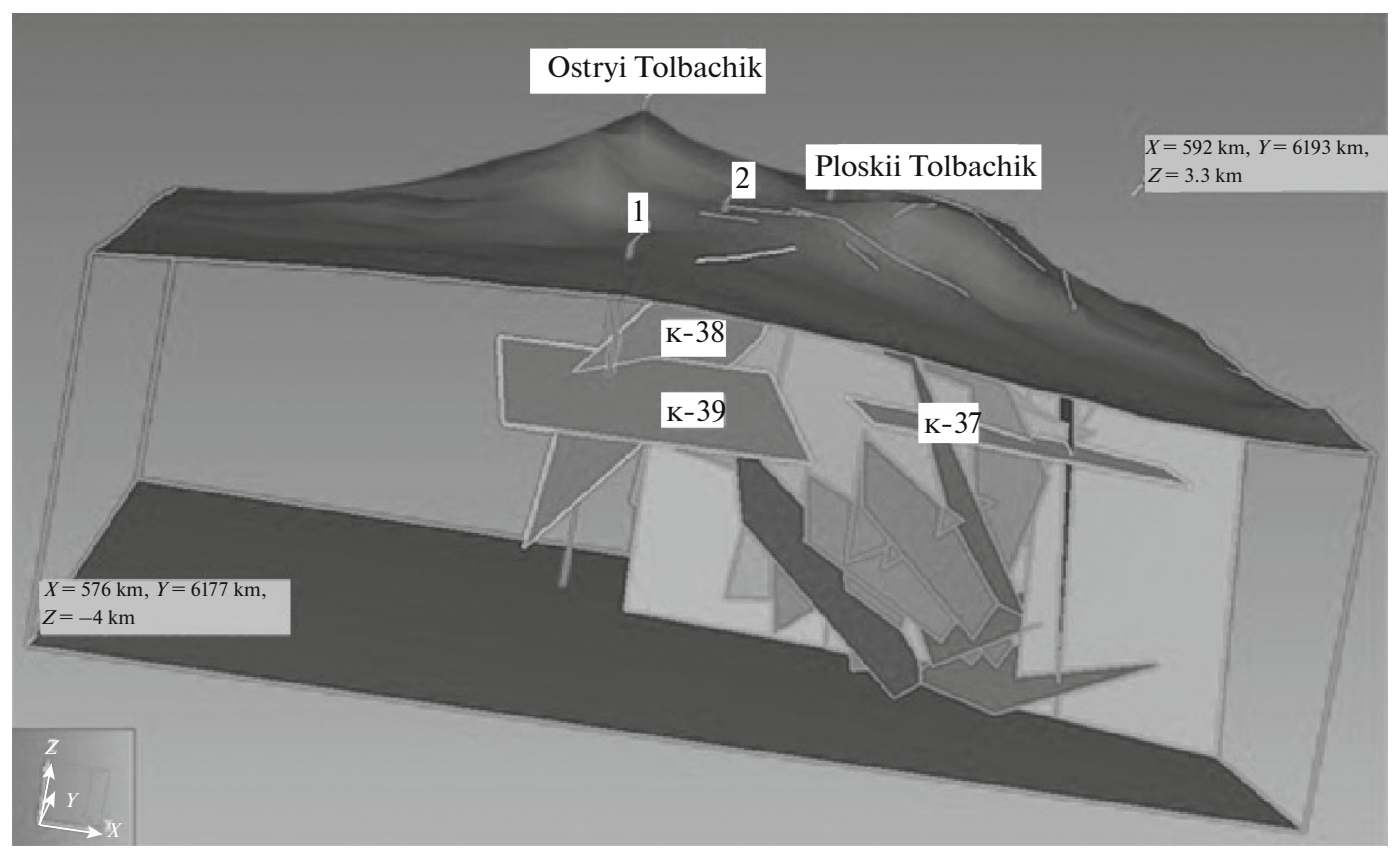

Fig. 5. A geomechanical interpretation of the local seismicity that lasted two days before the start of the Tolbachik eruption on November 27, 2012. Lighter shading in Fig. 5a shows dikes and sills (clusters 18-26) that were formed November 25-27, 2012 during the initial phase under dominant vertical stresses (geomechanical conditions NF: Sv $>$ Shmax $>$ Shmin). Lighter shading in Fig. 5b shows two sills and the magma-conducting dike (clusters 37-39) that were formed on November 27, 2012 immediately before the eruption under dominant horizontal north-northeast stresses (geomechanical conditions: Shmax $\gg \mathrm{Sv}=\mathrm{Shmin}$ ). (1) Menyailov crater, (2) Naboko crater. The boundary of the model in plan is shown by the rectangle in Fig. 1, the coordinate values in insets in this figure are in the UTM WGC-84 system.

volcano with a thermal power of $\sim 40 \mathrm{MW}$ in the jet and a discharge of $\sim 15 \mathrm{~kg} / \mathrm{s}$ of gas-steam fluid). By the end of December the thermal power (as determined from the discharge of steam) increased to reach values of $\sim 400 \mathrm{MW}$ and $\sim 150 \mathrm{~kg} / \mathrm{s}$, with ash appearing in the plume of the upper (main) vent. Since the end of April this renewal of activity continued in the form of steam and gas from the main vent only (as of early June 
(a)

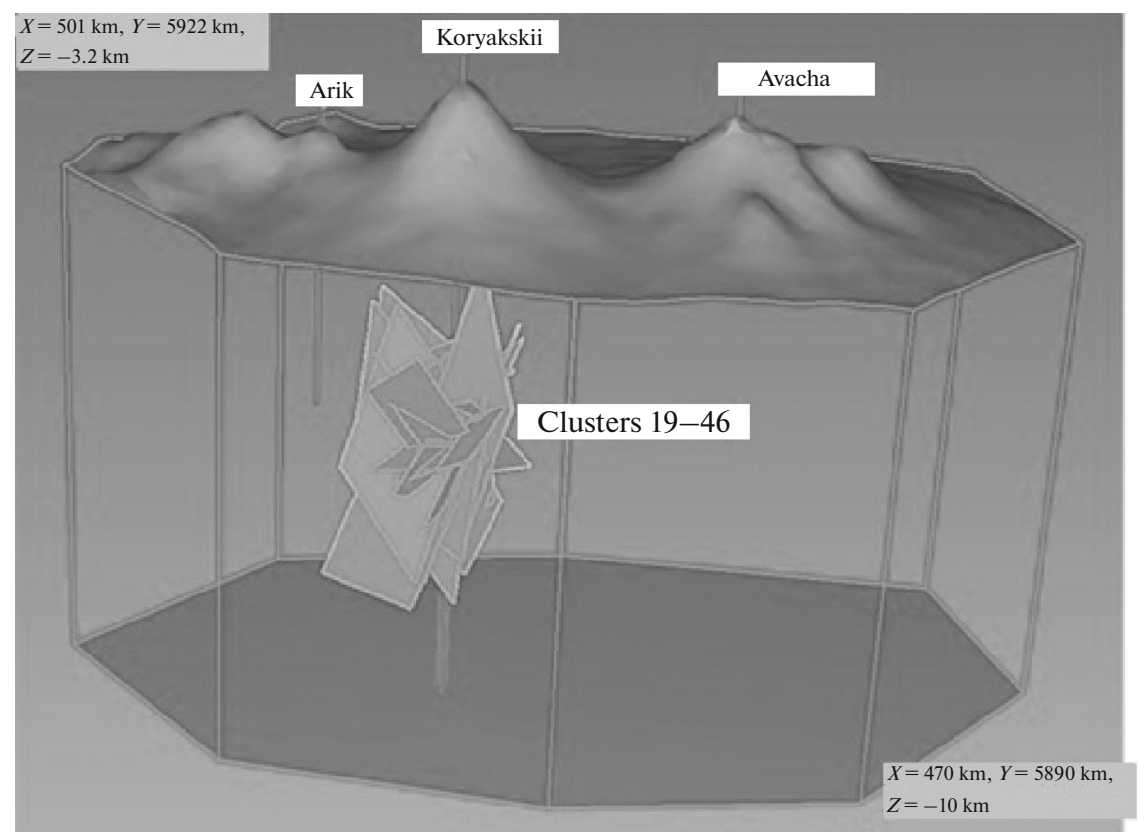

(b)

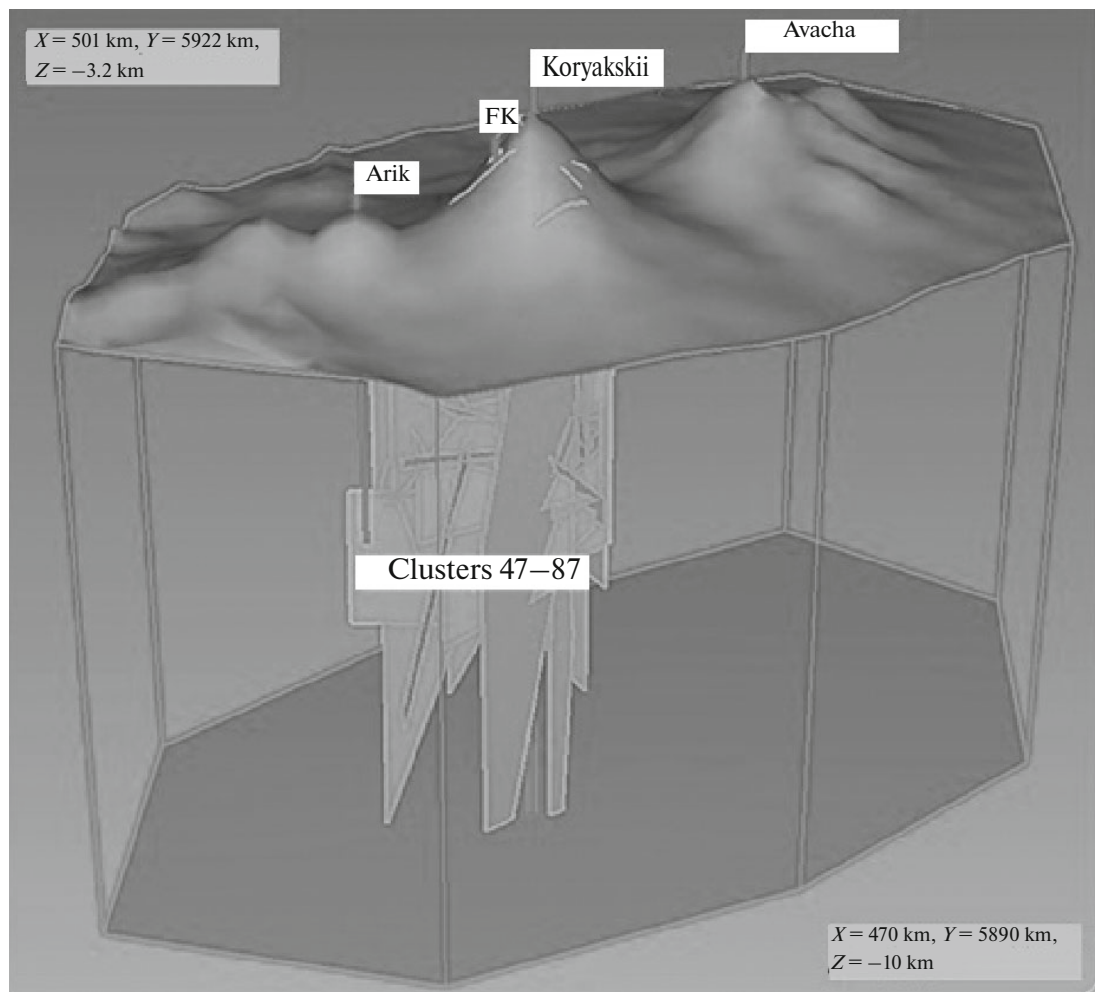

Fig. 6. A geomechanical interpretation of local seismicity beneath the Avacha-Koryakskii Volcanic Cluster. a, magma injections into the intermediate (crustal) magma chamber beneath Koryakskii Volcano at absolute depths of -3.0 to $-5.5 \mathrm{~km}$ near the southwestern base (July 2008 to January 2009)(clusters 19-46, see Fig. 7); b, magma injections into the nearly north-south zone beneath the north slope of Koryakskii Volcano accompanied by renewed summit steam-gas eruption of Koryakskii (February to April 2009). FK stands for Koryakskii fumarole. The boundary of the model in plan view is shown by a polygon in Fig. 2, the values of the coordinates in insets in this figure are in the UTM WGC-84 system. 
2009). Koryakskii Volcano discharged $50-150 \mathrm{~kg} / \mathrm{s}$ of steam in late 2008 and early 2009 , corresponding to a mean thermal power of 300-400 MW. The upper vent (the nearest to the crater) was the main one and had a steam discharge greater than that of the lower vent by an order of magnitude. The steam discharges from these vents were $\sim 170 \mathrm{~kg} / \mathrm{s}$ and $\sim 20 \mathrm{~kg} / \mathrm{s}$, respectively, in January 2009 . Koryakskii Volcano ejected $\sim 1.5$ million tons of steam during 4 months of the eruption (late December 2008 to late April 2009). Supposing that this steam was formed by boiling meteoric water due to cooling and crystallization of magma, this would correspond to a mass of emplaced magma equal to $\sim 3$ million tons at the lowest. Considering the comparatively slow cooling of magma as it interacted with water, and because of quenching, the mass of emplaced magma could have been an order of magnitude greater. The thermal powers of steam-gas plumes discharged by Koryakskii Volcano were estimated by V.V. Ivanov (2010) using a formula proposed by S.A. Fedotov.

\subsection{A Geomechanical Interpretation of the Local Seismicity}

A total of 3922 earthquakes were recorded (KB GS RAS data) to occur in the edifices and basements of the Koryakskii-Avacha Volcanic Cluster during the period between January 2000 and February 2013. Our treatment of this data set following the technique outlined in Section 2.2. revealed 1310 earthquakes that make up 164 plane-oriented clusters for the period between January 2008 and August 2011. A 3D visualization of this time sequence of clusters suggests the following 2008-2011 history of magma injection in the plumbing systems of the volcanoes.

(1) Injections of magma from deeper (primary) magma chambers in the range of depth reaching $10 \mathrm{~km}$ beneath Koryakskii and beneath Avacha volcanoes (January-June 2008). The magma injection from the primary magma chamber beneath Avacha was recorded in the form of a nearly north-south dike, while the injections into the Avacha volcanic cone produced clusters that mostly dip north at angles of $30^{\circ}-70^{\circ}$. The magma injections from the primary magma chamber beneath Koryakskii were recorded in the form of nearly north-south dikes that accompanied injection into the intermediate magma chamber beneath Koryakskii at absolute depths of -7000 to $-10000 \mathrm{~m}$ and that were also striking mostly nearly north-south that dipped at angles of $30^{\circ}-80^{\circ}$.

(2) Injections of magma into the intermediate (crustal) magma chamber beneath Koryakskii Volcano at absolute depths of -3.0 to $-5.5 \mathrm{~km}$ near its southwestern base at a distance of $1.5-4.0 \mathrm{~km}$ from the summit (July 2008 to January 2009) (Fig. 6a), which were accompanied by the start of the Koryakskii steam-gas eruption on November 23, 2008. The filling of the intermediate chamber resulted in the forma- tion of dikes striking at a range of azimuths and dipping at angles of $20^{\circ}-80^{\circ}$ (see Fig. 6a).

(3) Injections of magma in a nearly north-south zone $(7.5$ by $1.5 \mathrm{~km})$ at absolute depths of -10000 to $+3500 \mathrm{~m}$ beneath the north slope of Koryakskii Volcano, which was accompanied by a renewed summit steam-gas eruption of Koryakskii (February 2009 to April 2009) (see Fig. 6b). The filling of this nearly north-south zone with magma was recorded as the formation of inclined dikes that were mostly striking nearly north-south and dipped at angles of over $40^{\circ}$. Five of the dikes are closer to the summit part of Koryakskii Volcano.

(4) Continuing injections of magma in the nearly north-south zone (see above) beneath the north slope of Koryakskii Volcano that were accompanied by a summit steam-gas eruption of Koryakskii (AprilMay 2009). The zone was displaced approximately $1 \mathrm{~km}$ east relative to that described above (item 3 ). The filling of this zone with magma was recorded as the formation of dikes that strike at a range of azimuths and dipping at angles of over $35^{\circ}$. Two dikes were closer to the summit part of Koryakskii Volcano.

(5) Continuing injection of magma in the nearly north-south zone (see above, item 3) beneath the north slope of Koryakskii Volcano was accompanied by a decaying summit steam-gas eruption of Koryakskii (June 2009 to March 2010). The filling of this nearly north-south zone with magma was recorded as the formation of dipping dikes that were mostly striking NNW, and of sills. Eight dikes were closer to the summit part of Koryakskii Volcano. One of the dikes points toward the discharge area of the Koryakskii Narzany springs.

(6) Further injection of magma was largely into the cone of Avacha Volcano from October 2010 to May 2011, where dikes that were mostly striking NW and dipped at angles of below $85^{\circ}$; sills were identified. One dike was detected beneath the NW slope of Koryakskii Volcano in the area of the Izotov Springs (August 2, 2011), leading to an increase in the spring temperature (Kiryukhin et al., 2015a).

\section{DISCUSSION OF RESULTS USING MOHR'S DIAGRAMS}

The zone of active volcanoes in Kamchatka is generally under horizontal tension with graben-like features and normal faults predominating (the NF geomechanical state (Normal Fault, vertical stresses exceed the horizontal ones, $\mathrm{Sv}>\mathrm{SH}$ max $>\mathrm{SHmin}$ )). The transport of magma from primary or crustal magma chambers produces magma-induced fissures perpendicularly to the direction of minimum stress, Shmin, with fluid pressure that exceeded Shmin. It thus appears that the main primary fissures that transport magma are vertical dikes. When the pressure of the fluid (magma) exceeds the maximum shear stress 


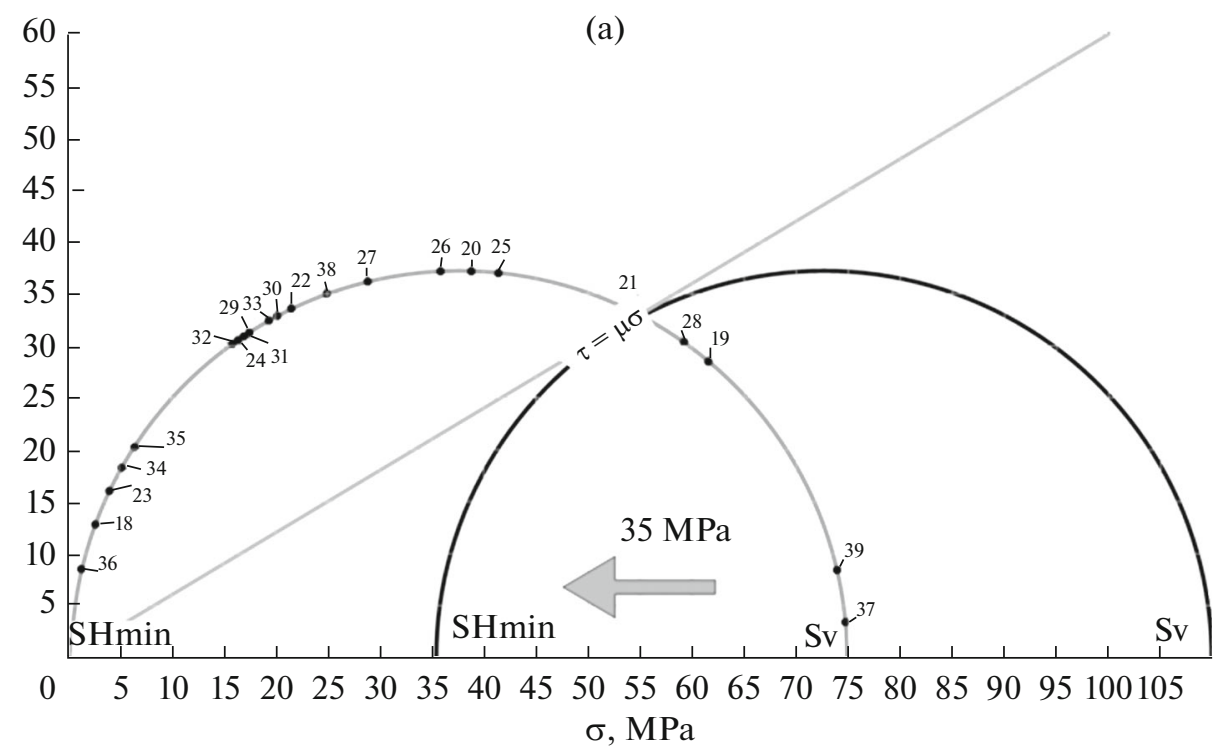

(b)

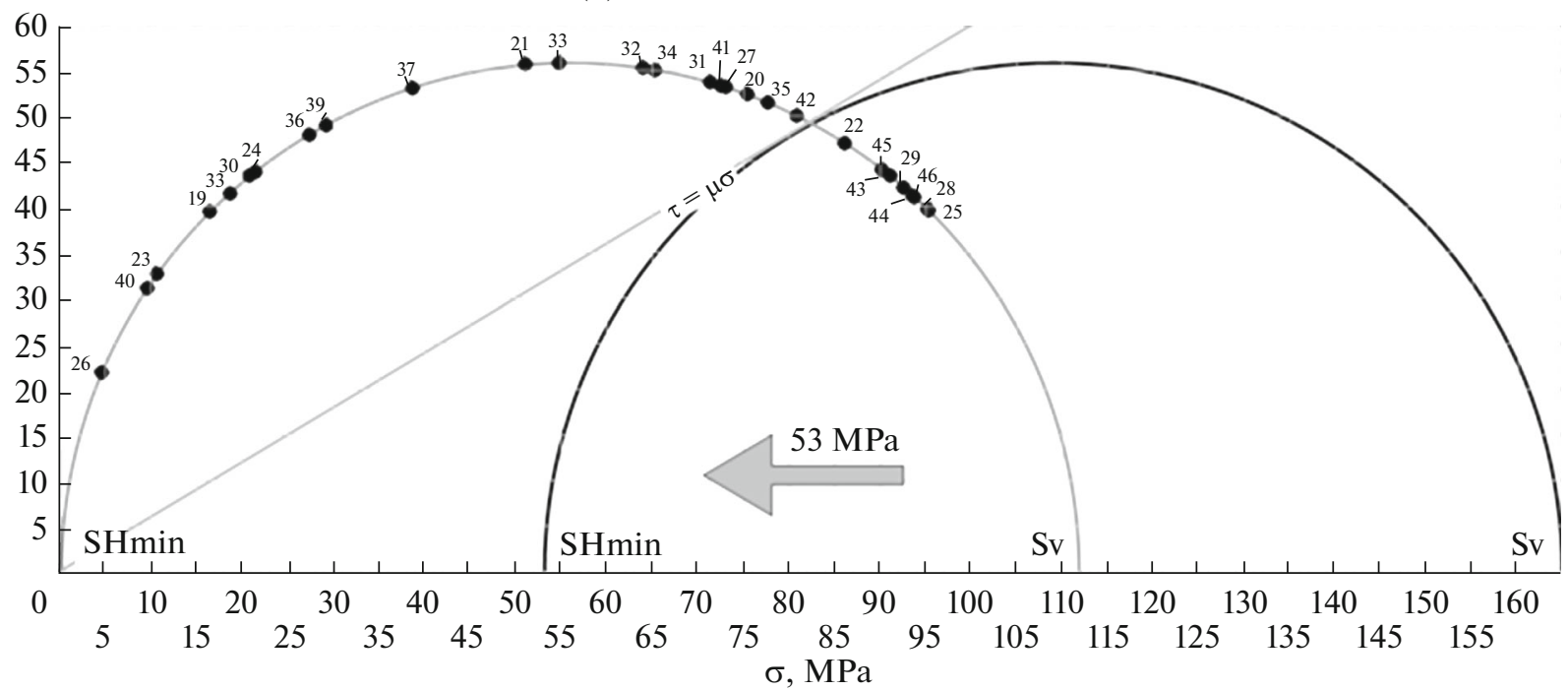

Fig. 7. Mohr's diagram that shows changes in stress during magma injection. The circle on the right covers the range of normal and shear stresses before the magma injection, that on the left is for the time after the injection; points with numerals show active fissures that were detected from seismic data: a, in the Tolbachik area (November 2012, depth 4 km); b, in the Koryakskii area (July 2008 to January 2009, depth $6 \mathrm{~km}$ ).

Note. For a point to be positioned in the circle, we rotate through an angle of $2 \beta$ from the horizontal axis (where $\beta$ is the angle of dip for a plane-oriented cluster, see column 2 in table).

$(\tau>\mu \sigma$, where $\tau$ is shear stress, $\sigma$ is normal stress, and $\mu \approx 0.6$ is the coefficient of internal friction), the result is to bring critically compressed strike-slip fissures to life. The dip angles of these fissures can most visually be determined from Mohr's diagrams. Conversely, with data on dip angles for active strike-slip fissures being available, one can evaluate the fluid pressure in the magma-induced fracture zone.

To illustrate the point, we plotted Mohr's diagrams in Fig. 7 for the Tolbachik volcanoes (as of 2012), for Koryakskii (as of 2008-2009), and for Avacha (2009). The Mohr circles represent the state of stress on vari- ously oriented areas relative to the principal stress axes. The coordinates for the Mohr circles in the diagrams are found from

$$
\begin{gathered}
\tau=0.5(\mathrm{~S} v-\mathrm{SH} \min ) \sin (2 \beta), \\
\sigma=0.5(\mathrm{~S} v+\mathrm{SH} \min ) \\
+0.5(\mathrm{~S} v-\mathrm{SH} \min ) \cos (2 \beta)-\mathrm{Pf},
\end{gathered}
$$

where $\beta$ is the angle of dip for plane-oriented clusters (see the table). The vertical stresses $\mathrm{Sv}$ are found in all cases as lithostatic pressure $\left(\mathrm{Sv}=\rho \mathrm{gH}, \rho=2800 \mathrm{~kg} / \mathrm{m}^{3}\right.$ (Gudmundsson, 2012)) at the point of magma injection (the 
mean depth of the centers of plane-oriented clusters, which is interpreted as the center of the magma chamber into which magma is injected). The values are $4 \mathrm{~km}$ for Tolbachik Volcano (2012), $6 \mathrm{~km}$ for Koryakskii (2008), and $1 \mathrm{~km}$ for Avacha Volcano (2009), with the horizontal stress Shmin being determined for extensional conditions (Normal Faults, NF) (Zoback, 2010, p. 132):

$$
\mathrm{SHmin}=\frac{\mathrm{Sv}_{\mathrm{m}}}{[(\mu 2+1) 0.5+\mu]^{2}} \approx \frac{\mathrm{SV}_{\mathrm{V}}}{3.1},
$$

\subsection{Tolbachik Volcano (2012)}

Mohr's diagram (see Fig. 7a) shows that the injection of magma at a depth of $4 \mathrm{~km}$ beneath Tolbachik Volcano occurred under a magma pressure of $35 \mathrm{MPa}$ and was accompanied by opening of fissures and by the formation of inclined high-angle dikes (see table, clusters $18,23,34,35,36$ ) with dip angles of $75^{\circ}-83^{\circ}$. Concurrently with this, strike-slip fissures were activated (clusters 18, 20-22, 24-27, and 29-33) whose dip angles were $32^{\circ}-62^{\circ}$. These fissures plot in Mohr's diagram in the fracture zone above the $\tau=\mu \sigma$ line. Two fissures that dipped at relatively low angles (clusters 19 and $28,25^{\circ}-27^{\circ}$ ) do not fall in the fracture zone in Mohr's diagram, being possibly triggered by a local stress at the top of the molten magma chamber. All the dikes and fissures mentioned above were most likely filled with magma with concurrent formation/repletion of the partially molten magma chamber whose dimensions were 5 by 3.5 by $3 \mathrm{~km}^{3}$ (approximately $50 \mathrm{~km}^{3}$ ). Magma broke out on the ground surface when one of the strike-slip fissures "found" a permeable nearly horizontal zone at an absolute altitude of approximately 0 (the base of the volcano, at the contact between Neogene volcanogenic-sedimentary deposits and Quaternary volcanic rocks), resulting in the formation of two sills (clusters 37 and 39) and a magma-conducting dike (cluster 38, dipping at an angle of $55^{\circ}$ along azimuth $300^{\circ}$ ), $5.5 \mathrm{~km}$ from the region of initial magma injection.

We wish to note that the strike of the magma-conducting dike (see table, cluster 38) and its direction of dip are consistent with the results of a geomechanical interpretation of ground deformation based on satellite observations (Lundgren et al., 2015). The open nearly north-south trending pinnate fissures abut on the dike from the south. The fissures were detected from the results of field work in September 2013. They provide evidence of a left lateral strike-slip component. The presence of shallow sills (see table, clusters 37 and 39) in the location where the eruption occurred is consistent with the presence of polygonal fissures on the ground surface (these were also detected by field work in 2013).

\subsection{Koryakskii Volcano (July 2008 to January 2009)}

Mohr's diagram (see Fig. 7b) shows that the magma pressure is estimated as $53 \mathrm{MPa}$ and most fissures fall in the fracture region in Mohr's diagram with angles of dip of $32^{\circ}-79^{\circ}$. That is to say, the fissures fit in the formation of strike-slip fissures during a vertical hydraulically induced fracture. Some of the fissures (clusters 22, 25, 28, 29, and 43-46) show lower angles of $\operatorname{dip}\left(23^{\circ}-29^{\circ}\right)$ and so cannot, by virtue of the geomechanical conditions for normal faults, be active. Low-angle fissures can be activated when a molten magma chamber occurs whose dimensions are comparable with those of the observed fissures. In that case the local stress along the normal to the chamber top is the greatest stress and the orientation of the magma-driven fracture along the radial direction is possible in geomechanical terms. Considering that the dimensions of the low-angle clusters 22 and 25 are estimated as 2.2 by $4.9 \mathrm{~km}$ and 3.9 by $4.7 \mathrm{~km}$, one can hypothesize comparable dimensions for the molten magma chamber that initiated similar clusters near the southwestern base of Koryakskii Volcano at absolute depths of -3.0 to $-5.5 \mathrm{~km}$.

\subsection{Koryakskii Volcano (February 2009 to March 2010)}

Further injection of magma beneath Koryakskii Volcano in the nearly north-south zone $(7.5$ by $1.5 \mathrm{~km})$ at absolute depths of -10000 to $+3500 \mathrm{~m}$ under the north slope of Koryakskii Volcano caused magmadriven fractures, nearly all of which occurred in the zone that is permitted according to Mohr's diagram. This provides evidence that the injection of magma was accompanied by opening of nearly vertical fissures $\left(84^{\circ}-87^{\circ}\right)$ and by dike emplacement, simultaneously with the generation of vertical fissures whose angles of dip were $34^{\circ}-82^{\circ}$. The highest density of magmainduced fractures was observed in a $7.5-\mathrm{km} \times 1.5-\mathrm{km} \times$ $4-\mathrm{km}$ volume $\left(45 \mathrm{~km}^{3}\right)$, which was filled with magma melt to varying degrees. The presence of clusters with lower angles of dip $\left(4^{\circ}-30^{\circ}\right)$ that do not fall in the zone of shear fracture indicates the possible existence of local molten magma chambers in the volume indicated above; these chambers can cause local stresses that can produce hydraulically induced fractures in the radial direction.

\subsection{Avacha Volcano (October 2010 to May 2011)}

Magma began to be injected into the Avacha cone following many fruitless attempts by the magma to reach the ground surface through the plumbing system beneath Koryakskii Volcano. Judging from the characteristics of plane-oriented clusters of microearthquakes and estimates of horizontal stresses, the subvertical open fissures and dikes were initiated at a pressure above $9 \mathrm{MPa}$ in the volcanic cone at a depth of approximately $1 \mathrm{~km}$. The presence of numerous nearly horizontal clusters dipping at $2^{\circ}-15^{\circ}$ indicates the 
A

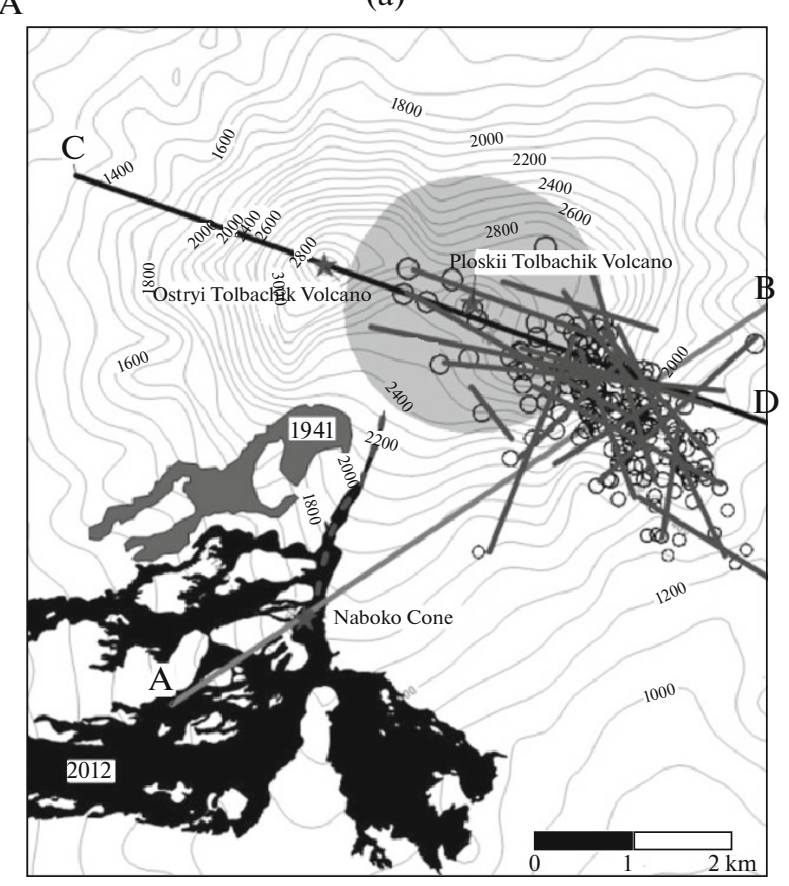

(b)

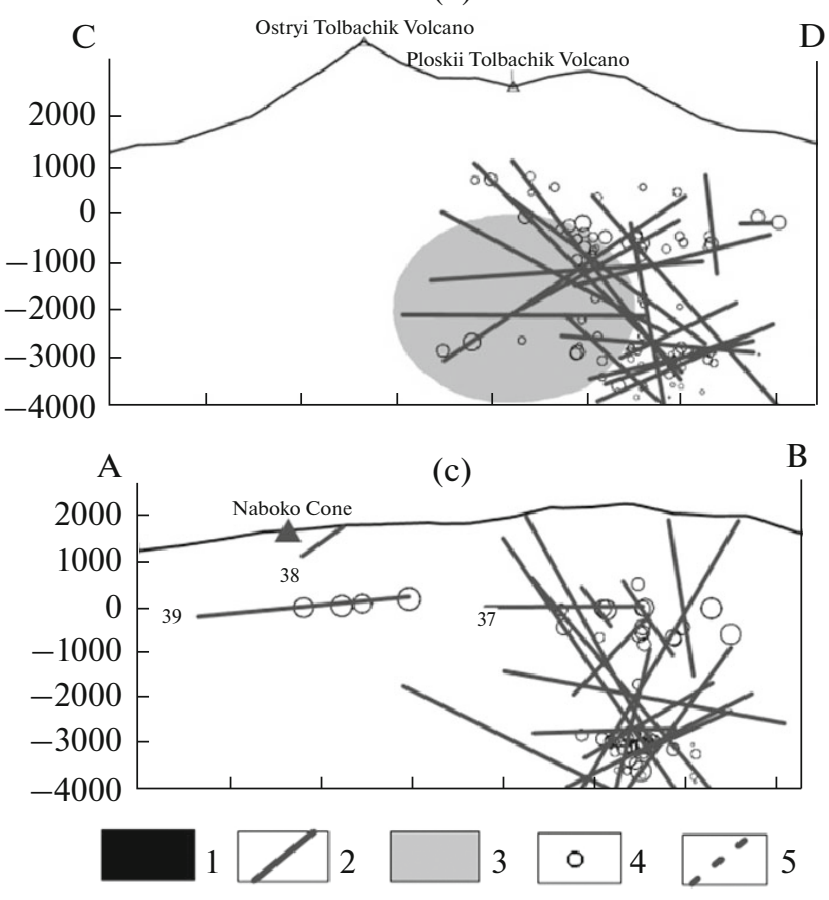

Fig. 8. Positions of dikes and fissures that were formed in the Ploskii Tolbachik area November 25-27, 2012 before the Tolbachik fissure eruption of November 27, 2012 as shown in a horizontal cross section at an absolute depth of $3 \mathrm{~km}$ (Fig. 8a) and on planes of vertical cross sections $\mathrm{AB}$ and $\mathrm{CD}$ (Figs. $8 \mathrm{~b}$ and $8 \mathrm{c}$ ). The boundary of the area in Fig. 8a is shown as a rectangle in Fig. 1. (1) outlines of lava flows discharged by the Tolbachik eruption of 2012-2013 (Volynets et al., 2013), see Fig. 1; (2) traces of planeoriented clusters (zones where high-angle dikes were emplaced, see table) in a horizontal cross section at an absolute depth of $3 \mathrm{~km}$ and on planes of vertical cross sections $\mathrm{AB}$ and CD; (3) projection of the outline of the peripheral magma chamber with dimensions indicated in (Fedotov et al., 2011) in a horizontal cross section at an absolute depth of $-3 \mathrm{~km}$ and on the plane of the vertical cross section $\mathrm{CD}$; (4) projections of the centers of local earthquakes onto a horizontal cross section at an absolute depth of $-3 \mathrm{~km}$ and vertical cross sections $\mathrm{AB}$ and $\mathrm{CD}$ (we show only the hypocenters of earthquakes within $1 \mathrm{~km}$ of the planes); (5) eruptive fissure of the November 27, 2012 TFE. Isolines show the topographic surface, numbers in the AB cross section mark magma-conducting sills ( 37 and 39) and dike (38) (for the numbering see table), ticks on the horizontal axes are at intervals of $2 \mathrm{~km}$.

existence of stratiform features, which allowed the magma melt to leak from the conduit to generate sills at absolute depths of +1600 to $+1900 \mathrm{~m}$ in the Avacha cone.

\section{CONCLUSIONS}

(1) It is shown here using data from the Tolbachik fissure basaltic eruption of 2012-2013, the steam-gas eruption of Koryakskii Volcano in 2008-2009, and the 2010 renewal of activity on Avacha Volcano, that the catalogs of local earthquakes connected to volcanic eruptions contain plane-oriented clusters of hypocenters. These can be interpreted as zones where sills and dikes were formed due to magma emplacement and magma-driven fractures in the host rocks beneath volcanoes during the precursory period and the occurrence of eruptions.

(2) A total of 22 plane-oriented clusters of earthquakes have been identified in the area of the Tolbachik Volcanoes 2 days before the onset of the November 27, 2012 eruption. The planes as identified are interpreted as zones of the emplacement of dikes and sills due to magma injection. Based on this interpretation, one would infer that the Tolbachik eruption was preceded by the emplacement of high-angle $\left(32^{\circ}-62^{\circ}\right)$ dikes that strike west-northwest at a magma pressure of $35 \mathrm{MPa}$ (at a depth of $4 \mathrm{~km}$ ) in the range of absolute depths between -4 and $+3 \mathrm{~km}$ southeast of the Ploskii Tolbachik edifice in a $5 \times 3.5 \mathrm{~km}^{2}$ area. Magma reached the ground surface after opening a permeable nearly horizontal zone at an absolute altitude of approximately zero, resulting in the formation of two sills and a magma-conducting dike (with a dip angle of $55^{\circ}$ and an azimuth of $300^{\circ}$ ). This took place in the Ploskii Tolbachik southwestern radial zone of fissures and cinder cones at a distance of $7 \mathrm{~km}$ from the middle of the region of previous emplacements (see Fig. 1 and Fig. 8). The mechanism of magma ascent found here is consistent with field measurements of jointing in the location of the 2013 eruption and with interpretation of satellite-based ground deformation observations (Lundgren et al., 2015). The zones of plane-oriented clusters in the horizontal cross section at an absolute depth of $-3 \mathrm{~km}$ and in planes of vertical cross sections are adjacent to the region of the peripheral magma cham- 
ber that Fedotov et al. (2011) hypothesized (Fig. 8), and which is a likely source of magma for the 2012-2013 lava eruption of Tolbachik.

(3) The 2008-2009 summit steam-gas eruption of Koryakskii Volcano was accompanied by 153 planeoriented earthquake clusters that are interpreted here as zones where dikes and sills were emplaced during magma injection. The precursory period of this eruption began with magma filling the crustal chamber (the top is at an absolute depth of $-3 \mathrm{~km}$ and the chamber is $2.5 \mathrm{~km}$ across) near the southwestern base of Koryakskii Volcano (July 2008 to January 2009). Further, magma was injected into a nearly northsouth zone $(7.5$ by $2.5 \mathrm{~km}$, the main range of absolute depths was between -2 and $-5 \mathrm{~km}$ ) in the northern sector of Koryakskii Volcano simultaneously with the most intense period of the summit steam-gas eruption (February 2009 to March 2010). The magma injection at a magma pressure of $53 \mathrm{MPa}$ (at a depth of $6 \mathrm{~km})$ was accompanied by dike $\left(84^{\circ}-87^{\circ}\right)$ emplacement simultaneously with the formation of inclined dikes (dip angles were $34^{\circ}-82^{\circ}$ ). The highest density of magma-driven fracturing was observed in a volume of $45 \mathrm{~km}^{3}$, which was filled with a magma melt to varying degrees of saturation. The presence of lower-angle clusters that dip $4^{\circ}-30^{\circ}$, which do not fall in the zone of shear fracture in Mohr's diagram, indicates the possible existence of local molten magma chambers and permeable stratiform reservoirs in the volume. Following the saturation of the plumbing system beneath Koryakskii Volcano, magma was injected into the cone of Avacha Volcano (2010).

The quality and completeness of the available data set and the uncertainty of hypocenter location determine the validity of this study of the mechanism of activity for three volcanoes (Ploskii Tolbachik and the Koryakskii-Avacha Volcanic Cluster), while the quality of the data sets are dependent on the KB GS RAS catalogs, which are undergoing continual updating and refinement of hypocenter location. For this reason some of the above results are preliminary in nature and can be refined in the future, when more complete and accurate data on earthquake coordinates become available.

\section{ACKNOWLEDGMENTS}

We thank T.V. Rychkova, V.K. Grigor'ev, N.B. Zhuravlev, P. Lundgren, S. Samsonov, A.B. Belousov, M.G. Belousova, T.G. Churikova, I.K. Dubrovskaya, D.V. Mel'nikov, Ya.D. Murav'ev, V.N. Chebrov, I.F. Delemen, V.K. Lemzikov, S.L. Senyukov, E.V. Chernykh and V.V. Ivanov for help in the organization of field work, data processing, and discussion of the results.

This work was supported by project no. 16-1710008.

\section{REFERENCES}

Belousov, A., Belousova, M., Edwards, B., et al., Overview of the precursors and dynamics of the 2012-2013 basaltic fissure eruption of Tolbachik Volcano, Kamchatka, Russia, J. Volcanol. Geotherm. Res., 2015, no. 307, pp. 22-37.

Bol'shoe treshchinnoe Tolbachinskoe izverzhenie, 1975-1976 gg., Kamchatka (The Great Tolbachik Fissure Eruption, 1975-1976, Kamchatka), Fedotov, S.A., Ed., Moscow: Nauka, 1984 [Available in English: The Great Tolbachik Fissure Eruption: Geological and Geophysical Data, 1975-1976, Fedotov, S.A. and Marchinin, E.K., Eds., Cambridge University Press, 1983].

Fedotov, S.A., Magmaticheskie pitayushchie systemy i mekhanizm izverzhenii vulkanov (Plumbing Systems and the Mechanism of Volcanic Eruptions), Moscow: Nauka, 2006.

Fedotov, S.A., Balesta, S.T., Dvigalo, V.N., et al., The New Tolbachik volcanoes, in Deistvuyushchie vulkany Kamchatki (Active Volcanoes of Kamchatka), vol. 1, Fedotov, S.A. and Masurenkov, Yu.P., Eds., Ch. X, Moscow: Nauka, 1991, pp. 275-279.

Fedotov, S.A., Sugrobov, V.M., Utkin, I.S., and Utkina, L.I., On the possibility of using heat stored in the magma chamber of the Avachinsky Volcano and the surrounding rock for heat and power supply, J. Volcanol. Seismol., 2007, vol. 1, no. 1, pp. 28-41.

Fedotov, S.A., Utkin, I.S., and Utkina, L.I., The peripheral magma chamber of Ploskii Tolbachik, a Kamchatka basaltic volcano: Activity, location and depth, dimensions, and their changes based on magma discharge observations, J. Volcanol. Seismol., 2011, vol. 5, no. 6, pp. 369-385.

Fedotov, S.A., Slavina, L.B., Senyukov, S.L., and Kuchai, M.S., Seismic processes and magma movement occurring during the Great Tolbachik Fissure Eruption of 19751976 and during the Tolbachik Fissure Eruption of 2012-2013 in Kamchatka Peninsula, Geofizicheskie Protsessy i Biosfera, 2014, vol. 11, no. 1, pp. 3-30.

Gudmundsson, A., Magma chambers: Formation, local stresses, excess pressures, and compartments, J. Volcanol. Geotherm. Res., 2015, no. 237-238, pp. 19-41.

Ivanov, V.V., A burst of activity on Koryakskii Volcano, Kamchatka in late 2008 and early 2009: Estimates of heat release, aqueous fluid discharge, a conceptual model for magma ascent, and a forecast of the evolution of the eruption, in Materialy konferentsii, posvyashchennoi Dnyu vulkanologa, 30-31 marta 2009g. (Proc. conf. devoted to Volcanologist's Day, March 30-31, 2009), Petropavlovsk-Kamchatskii: IViS DVO RAN, 2010, pp. 24-39.

Ivanov, V.V., The role of fluids in the generation of microearthquakes on volcanoes and in hydrothermal systems, in Tezisy XVIII ezhegodnoi nauchnoi konferentsii, posvyashchennoi Dnyu vulkanologa "Vulkanizm i svyazannye s nim protsessy", 30 marta-1 aprelya $2015 \mathrm{~g}$. (Abstracts of reports at the 18th annual conference devoted to Volcanologist's Day "Volcanism and Related processes", March 1 to April 1, 2015), Petropavlovsk-Kamchatskii: IViS DVO RAN, 2015, pp. 164-169. 
Kiryukhin, A.V., Manukhin, Yu.F., Fedotov, S.A., et al., Geological fluids in the Avacha-Koryakskii volcanogenic basin, Kamchatka, Geoekologiya, Inzhenernaya Geologiya, Gidrogeologiya, Geokriologiya, 2015a, no. 4, pp. 306-320.

Kiryukhin, A.V., Fedotov, S.A., and Kiryukhin, P.A., A geomechanical interpretation of the local seismicity prior to the November 27, 2012 eruption on Tolbachik Volcano, in Sbornik 18-i konferentsii, posvyashchennoi Dnyu vulkanologa (Collected papers delivered at the 18th conference devoted to Volcanologist's Day), Petropavlovsk-Kamchatskii: IViS DVO RAN, 2015b, pp. 266-269.

Kugaenko, Yu.A., Titkov, N.N., Saltykov, V.A., and Voropaev, P.V., An analysis of precursory phenomena for the 2012-2013 Tolbachik Fissure Eruption: Seismicity parameters and crustal strain as inferred from data supplied by the system of multidisciplinary monitoring of volcanic activity in Kamchatka, J. Volcanol. Seismol., 2007, vol. 1, no. 1, pp. 1-27.

Kugaenko, Yu.A., Saltykov, V.A., and Voropaev, P.V., An analysis of the seismicity that preceded the Tolbachik Fissure Eruption of 2012-2013, in Zemletryaseniya Rossii v 2012 g. (Earthquakes in Russia in the Year 2012), Obninsk: GS RAN, 2014, pp. 82-86.

Lundgren, P., Kiryukhin, A., Milillo, P., and Samsonov, S., Dike model for the 2012-2013 Tolbachik eruption con- strained by satellite radar interferometry observations, J. Volcanol. Geotherm. Res., 2015, no. 307, pp. 79-88.

Senyukov, S.L., Nuzhdina, I.N., and Chebrov, V.N., Kamchatka volcanoes, in Zemletryaseniya Rossii v $2012 \mathrm{~g}$. (Earthquakes in Russia in the Year 2012), Obninsk: GS RAN, 2014, pp. 77-81.

Senyukov, S.L., Nuzhdina, I.N., Droznina, S.Ya., et al., Seismic monitoring of the Plosky Tolbachik eruption in 2012-2013 (Kamchatka Peninsula, Russia), J. Volcanol. Geotherm. Res., 2015, no. 307, pp. 47-59.

Sigmundsson, F., Hooper, A., Hreinsdorttir, S., et al., Segmented lateral dyke growth in a rifting event at Barrparbunga volcanic system, Iceland, Nature, 2015, vol. 517, pp. 191-194. doi 10.1038/nature 14

Volynets, A.O., Melnikov, D.V., and Yakushev, A.I., First data on composition of the volcanic rocks of the IVS 50th anniversary Fissure Tolbachik eruption (Kamchatka), Doklady Earth Sciences, 2013, vol. 452(1), pp. 953-957. doi 10.1134/S1028334X13090201

Zemletryaseniya Rossii v $2012 \mathrm{~g}$. (Earthquakes in Russia in the year 2012), Obninsk: GS RAN, 2014.

Zoback, M.D., Reservoir Geomechanics, Cambridge: University Press, 2010.

Translated by A. Petrosyan 